\title{
GILLES DELEUZE
}

\author{
Daniel W. Smith
}

Gilles Deleuze ${ }^{1}$ was one of the most influential and prolific French philosophers of the second half of the twentieth century. "I consider him to be the greatest contemporary French philosopher," Michel Foucault once said, adding famously that "perhaps one day this century will be known as Deleuzian." ${ }^{2}$ Despite such accolades, Deleuze remains difficult to classify as a thinker. The labels most frequently used to interpret contemporary French philosophy are inapplicable to Deleuze, since he was neither a phenomenologist, a structuralist, a hermeneutician, a Heideggerian, nor even a "postmodernist." Whereas many French philosophers (Levinas, Ricoeur, Derrida, Lyotard) began their careers with studies of Husserl, Deleuze wrote his first book on Hume, and always considered himself an empiricist. Most dauntingly perhaps, his published oeuvre at first sight seems to be marked by a rather bewildering eclecticism, including constructive works such as Difference and Repetition and Logic of Sense, numerous monographs in the history of philosophy (on Hume, Nietzsche, Bergson, Kant, Spinoza, and

1. Gilles Deleuze (January 18, 1925-November 4, 1995; born and died in Paris, France) was educated at the Sorbonne (1944-48), and received a doctorat d'état there in 1968. His influences included Bergson, Heidegger, Hume, Kant, Lautmann, Leibniz, Maimon, Nietzsche, Sartre, Simondon, and Spinoza, and he held appointments at the Lycée d'Amiens (1948-53), Lycée d'Orleans (1953-55), Lycée Louis-le-Grand (1955-57), Sorbonne (1957-60), Centre National de Recherche Scientifique (1960-64), University of Lyon (1964-69), and University of Paris VIII-Vincennes-St. Denis (1969-87).

2. The first quote is from Foucault, "La Scène de la philosophie" (1978 interview with Moriaki Watanabe), in Dits et écrits 1954-1988, tomes 1-4, Daniel Defert and François Ewald (eds) (Paris: Gallimard, 1994), vol. 3, 589; the second is from Foucault, "Theatrum Philosophicum," in The Essential Works of Foucault, 1954-1984. Volume 2: Aesthetics, Method, Epistemology, James D. Faubion (ed.) (New York: New Press, 1998), 343. 
Leibniz), as well as works dealing with clinical psychiatry, psychoanalysis, politics, the cinema, literature, and art. Although a number of these works have become classics in their respective fields, the unity of Deleuze's oeuvre is not always apparent, even to serious readers of his work. It is no doubt the singular nature of his work that is the most characteristic feature of Deleuze's philosophy. "Those who really brought something new [to contemporary philosophy]," Michel Serres has commented:

did not take the superhighways - for example, Gilles Deleuze. He disengaged himself from the traditional history of philosophy, from the human sciences, from epistemology - an excellent example of the dynamic movement of a free and inventive thought. ... The greatest praise I can give to him is to say that philosophical thinking made him truly happy, profoundly serene. ${ }^{3}$

Deleuze was born in Paris, near the Arc de Triomphe, and lived there, except for a few interludes elsewhere, for the rest of his life. He was the second son of a conservative, middle-class engineer, and received his elementary education in the French public school system. When the Germans invaded France in 1940 , Deleuze's family was on vacation in Normandy, and he spent a year being schooled there. Deleuze traced his own initiation into literature, at age fourteen, to a curious encounter on the beaches at Deauville with a teacher named Pierre Halbwachs (son of the sociologist Maurice Halbwachs), who introduced him to writers such as André Gide and Charles Baudelaire. He completed his baccalauréat in 1943 at his neighborhood school in Paris, the Lycée Carnot, and began to read philosophy during the "términale" year, under the influence of his professor, M. Vial. Early on, he recalled, philosophical concepts struck him with the same force as literary characters, having their own autonomy and style. He soon began to read philosophical works with the same animation and engagement as literary texts, and decided that philosophy would be his vocation. During the Occupation, Deleuze's older brother Georges, then a student at the military school St. Cyr, was arrested by the Nazis for resistance activities and deported; he died on the train to a concentration camp. ${ }^{4}$

3. Michel Serres, Éclaircissements: Entretiens avec Bruno Latour (Paris: François Bourin, 1992), 61-2, 66; published in English as Conversations on Science, Culture, and Time, Roxanne Lapidus (trans.) (Ann Arbor, MI: University of Michigan Press, 1995), 39-40, translation modified.

4. Deleuze never referred to his brother's death in any of his writings, and it does not seem to have had a great influence on his later political views. François Dosse, in Gilles Deleuze et Félix Guattari: Biographie croisée (Paris: La Découverte, 2007) discusses Deleuze's complex personal reaction to Georges' death. On the one hand, Deleuze felt his brother's loss deeply: 
After the Liberation, Deleuze immersed himself in his university studies. He undertook his khâgne (an intensive year of preparatory studies) at the prestigious Lycée Henri-IV, and then studied the history of philosophy at the Sorbonne under the tutelage of Jean Hyppolite and Ferdinand Alquié ("two professors I loved and admired enormously"5), as well as Georges Canguilheim and Maurice de Gandillac. He was immediately recognized by both his teachers and peers to be an exceptional student, and easily excelled in his studies. ${ }^{6}$ In 1947, he received his diplôme d'études supérieures from the Sorbonne with a thesis on Hume, directed by Hyppolite and Canguilhem. In an era dominated by phenomenology and "the three H's" (Hegel, Husserl, Heidegger), Deleuze's decision to write on empiricism and Hume was already a provocation, early evidence of the heterodox tendencies of his thought. A revised version of the Hume thesis would be published in 1953, as Deleuze's first book, under the title Empiricism and Subjectivity: An Essay on Hume's Theory of Human Nature. In 1948, Deleuze passed the agrégation examination in philosophy, along with Louis Althusser and François Châtelet, and was assigned to a teaching position at the Lycée d'Amiens. ${ }^{7}$ At the time, like many of his peers, he was as influenced by the writings of Jean-Paul Sartre as he was by his academic mentors; he devoured Being and Nothingness when it appeared in 1948. When Sartre refused

Jean-Pierre Faye, a childhood friend, recalled seeing Deleuze at the burial of another young man who had died in a concentration camp, "his face convulsed in pain, overwhelmed" (ibid., 113). On the other hand, Deleuze's parents idolized Georges for his heroic act, and afterwards treated Gilles as a secondary and relatively insignificant sibling, which only hastened Deleuze's break from his familial milieu. Michel Tournier later recalled, "His parents devoted a veritable cult to his older brother and Gilles did not forgive his parents for their exclusive admiration for Georges. He was the second child, the mediocre one, whereas Georges was a hero" (ibid., 112).

5. Gilles Deleuze and Claire Parnet, Dialogues, Hugh Tomlinson and Barbara Habberjam (trans.) (New York: Columbia University Press, 1987), 12.

6. François Châtelet, in his autobiographical text, Chronique des idées perdues, relates the following story about Deleuze's audacity as a student: "I preserve the memory of a reading by Gilles Deleuze, who had to treat I don't know what classic theme of Nicholas Malebranche's doctrine before one of our most profound and most meticulous historians of philosophy and who had constructed his demonstration, solid and supported with peremptory references, around the sole principle of the irreducibility of Adam's rib. At the expression of this adopted principle, the master turned pale, and obviously had to keep himself from intervening. As the exposition unfolded, the indignation was changed into incredulity, and then, at the moment of peroration, into admiring surprise. And he justly concluded by making us all return the next week with our own analysis of the same theme" (Chronique des idées perdues [Paris: Éditions Stock, 1977], 46). The teacher Châtelet is referring to was probably Henri Gouhier (I would like to thank Alan Schrift for this identification).

7. Didier Eribon, Michel Foucault, Betsy Wing (trans.) (Cambridge, MA: Harvard University Press, 1991), 33. 
the Nobel Prize in 1964, Deleuze would pen a moving tribute to him entitled "He Was My Teacher."

Deleuze, however, quickly rebelled against the academic training he was receiving in the French university system, with its emphasis on close readings of classical canonical texts. " "I belong to a generation," he later recalled:

one of the last generations, that was more or less assassinated by the history of philosophy. The history of philosophy plays an obvious repressive role in philosophy, it is a properly philosophical Oedipal complex: "All the same, you dare not speak in your own name until you have read this and that, and that on this, and this on that." Many members of my generation never broke free of this; others did by inventing their own particular methods and new rules, a new approach. ${ }^{10}$

Deleuze's own way of breaking free took a variety of forms. He tended to seek out and retrieve forgotten figures, such as Bergson, who had faded into obscurity and disrespect by the postwar period. ${ }^{11}$ He read and championed lesser-known figures, including both contemporaries (Lautmann, Simondon, Ruyer ${ }^{12}$ ) and historical

8. Gilles Deleuze, "He Was My Teacher," in Desert Islands and Other Texts (1953-1974), David Lapoujade (ed.), Michael Taormina (trans.) (New York: Semiotext(e), 2004). This text originally appeared in the French journal Arts (November 28, 1964), one month after Sartre refused the Nobel Prize in Literature.

9. For an analysis of the institutional context of French philosophy, see Alan D. Schrift, TwentiethCentury French Philosophy: Key Themes and Thinkers (Malden, MA: Blackwell, 2006), especially Appendix 1, "Understanding French Academic Culture," 188-208.

10. Gilles Deleuze, Negotiations, 1972-1990, Martin Joughin (trans.) (New York: Columbia University Press, 1995), 5, translation modified.

11. Claude Lévi-Strauss gave voice to a widespread opinion when he joked that Bergson had "'reduced being and things to a state of mush in order to bring out their ineffability," and Deleuze said that even friends laughed at him for writing on Bergson. (The quote from LéviStrauss appears in Richard Rorty's review of Deleuze's Nietzsche and Philosophy "Unsoundness in Perspective," Times Literary Supplement.) Deleuze lamented that "they have no idea how much hatred Bergson managed to stir up in the French university system at the outset, and how he became a focus for all sorts of crazy and marginal people" (Deleuze, Negotiations, 6, translation modified). Deleuze's 1964 book Bergsonism is now credited with having almost single-handedly brought about a revival of interest in Bergson's work.

12. Gilbert Simondon (1924-89), a French philosopher whose work focused primarily on the issues of individuation and technology, was the author of L'Individu et sa genèse physicobiologique (The individual and its physical-biological genesis). Albert Lautmann (1908-44), a French philosopher of mathematics, shot by the German authorities in Toulouse as an escaped prisoner of war, was the author of Essai sur les Notions de Structure et d'Existence en Mathématiques (Essay on the notions of structure and existence in mathematics). Raymond Ruyer (1902-87), a prolific French philosopher, known for his work in the philosophy of 
figures (Bordas-Demoulin, Hoëné-Wronski, Maimon, among many others ${ }^{13}$ ). He created novel sequences in the history of philosophy, reading Stoic logic in conjunction with Lewis Carroll's work, for example, or linking Duns Scotus's concept of univocity with the work of Spinoza and Nietzsche. Most importantly, perhaps, he read even the major figures of the tradition in new ways. "I suppose the main way I coped with things at the time," he explained in an oft-cited text:

was to see the history of philosophy as a kind of buggery or (it amounts to the same thing) an immaculate conception: I saw myself as taking an author from behind, and giving him a child that would be his own, yet monstrous. It was very important that the child was his own, because the author had to say everything I was making him say. But it was also necessary for the child to be monstrous, because it had to pass through all sorts of decenterings, slidings, dislocations, and secret emissions that gave me much pleasure. ${ }^{14}$

Yet this seemingly flippant remark should not obscure the respect and admiration Deleuze had for all the authors he worked on. "My ideal, when I write about an author," he later added, "would be to write nothing that would cause him sadness, or if he is dead, that might make him weep in his grave."15

In order to write and think, Deleuze explained, he needed to work with "intercessors" with whom he could enter into a kind of becoming (past philosophers were intercessors of this type, as was Félix Guattari, in the present). ${ }^{16}$ When

biology and information theory, was the author of Néofinalisme (Neo-finalism) and La Genèse des formes vivantes (The genesis of living forms).

13. Salomon Maimon (1752-54?-1800), a German philosopher, born of Jewish parentage in Poland, was one of the earliest and most profound critics of Kant's critical philosophy and the author of the Versuch über die Transcendentalphilosophie (Essay on transcendental philosophy), which attempted to ground post-Kantian philosophy on a Leibnizian reinterpretation of the calculus. Józef Maria Hoëné-Wronski (1778-1853), a prolific Polish mathematician who developed a messianic and mystical system of philosophy, is best remembered for his theory of infinite series as developed in works such as Philosophie de l'infini (Philosophy of the infinite) and Philosophie de la technie algorithmique (Philosophy of the algorithmic technique). Jean Baptiste Bordas-Demoulin (1798-1859), a French philosopher who attempted to reconcile Christianity with modern civilization, was the author of Le Cartésianisme ou la véritable rénovation des sciences (Cartesianism, or the true rejuvenation of the sciences), in the context of which he offered a Platonic interpretation of the calculus. $\left[{ }^{*}\right]$ For a discussion of Salomon Maimon and his critique of Kant, see the essay by Richard Fincham in History of Continental Philosophy: Volume 1.

14. Deleuze, Negotiations, 6, translation modified.

15. Deleuze and Parnet, Dialogues, 119.

16. See Deleuze, Negotiations, 121-34. The French term "Intercesseurs" in the title is translated into English as "Mediators." 
reading Deleuze's monographs, one literally enters a "zone of indiscernibility" between Deleuze's thought and the philosopher he is writing on (free indirect discourse): there is a becoming-Deleuze of Leibniz, for instance, as much as there is a becoming-Leibniz on Deleuze's part. This accounts for the complexities one encounters in reading Deleuze's texts: one moves from a fairly straightforward explication of the thinker at hand, to a more specifically Deleuzian interpretation, which often makes use of concepts incorporated from the outside (for instance, Deleuze interprets Spinoza in terms of Duns Scotus's concept of "univocity", and Leibniz in terms of the mathematical concept of "singularities," even though neither of these terms appears in Spinoza's or Leibniz's texts); and finally, one reaches a creative point where Deleuze pushes the thought of the thinker at hand to its differential or immanent limit. Despite his occasional use of such language, it is impossible to categorize figures in the history of philosophy simply as Deleuze's "friends" or "enemies": he was as indebted to Kant (a supposed enemy) as he was critical of Bergson (a supposed friend).

It is sometimes joked that "continental" philosophers pretend they have read everything, whereas "analytic" philosophers pretend they have read nothing. In Deleuze's case, this caricature comes close to the truth: Jean-François Lyotard once called him "the library of Babel." ${ }^{17}$ His writings are not only strongly grounded in the history of philosophy, but are also dotted with references to numerous nonphilosophical domains, including differential calculus, thermodynamics, geology, molecular biology, population genetics, ethology, embryology, anthropology, psychoanalysis, economics, linguistics, and even esoteric thought. But this erudition was never in the service of a mere acquisition of knowledge or the mastery of a discipline, but rather a kind of passage to the limit: the conditions of thought, Deleuze liked to say, must always be drawn, not from the model of knowledge, but from the process of learning.

We write only at the frontiers of our knowledge, at the border which separates our knowledge from our ignorance and transforms the one into the other .... To satisfy ignorance is to put off writing until tomorrow - or rather, to make it impossible ... ${ }^{18}$

One always speaks from the depths of what one does not know. ${ }^{19}$

Deleuze and Guattari would almost elevate this link between erudition and ignorance into a principle of their writing: "We claim the right to a radical laxity,

17. Jean-François Lyotard, "Il était la bibliothèque de babel," Liberation (November 9, 1995).

18. Gilles Deleuze, "Preface," in Difference and Repetition, Paul Patton (trans.) (New York: Columbia University Press, 1994), xxi.

19. Deleuze, Negotiations, 7, translation modified. 
a radical incompetence." 20 "We would like to speak in the name of an absolute incompetence." 21 The novelist Michel Tournier, who studied with Deleuze at the Sorbonne, recalled in his memoir that, even as a student, Deleuze already manifested this ability to transmute the thoughts he incorporated from others: "He possessed extraordinary powers of translation and rearrangement: all the tired philosophy of the curriculum passed through him and emerged unrecognizable but rejuvenated, with an air of freshness, undigestedness, and raw newness, utterly startling and discomfiting our weakness and laziness." 22

During the decade between 1953 and 1962, Deleuze published little, and moved among various teaching positions in Paris and the provinces. He later referred to this period, somewhat glibly, as "a hole in my life," but in fact it was a period of intense study and activity, during which Deleuze was quietly pursuing his own unique path in philosophy. During the 1956-57 academic year, for instance, he gave a hypokhâgne course at the Lycée Louis-le-Grand entitled "Qu'est-ce que fonder?" (What is grounding?), which already included much of the material that would later appear in Difference and Repetition. ${ }^{23}$ In August 1956 he married Denise Paul Grandjouan ("Fanny"), who became the French translator of D. H. Lawrence, and with whom Deleuze would have two children, Julien (b. 1960) and Emilie (b. 1964). In 1962 his groundbreaking study Nietzsche and Philosophy - an anti-Hegelian polemic that reads Nietzsche in the context of the post-Kantian tradition - was published to considerable acclaim, cementing Deleuze's reputation in academic circles. ${ }^{24}$ During the remaining years of the 1960s, Deleuze published a book a year, each of them devoted to the work of a particular philosopher or literary figure: Kant (1963), Proust (1964), Nietzsche (1965), Bergson (1966), Sade and Masoch (1967), and Spinoza (1968). Deleuze later considered these to be years of apprenticeship: the books were preparatory sketches for the great canvases of Difference and Repetition and Logic of Sense.

In 1962, shortly after the publication of Nietzsche and Philosophy, Deleuze met Foucault in Clermont-Ferrand, at the home of Jules Vuillemin, who had just been elected to the Collège de France. Foucault had suggested that Deleuze might replace Vuillemin at the University of Clermont-Ferrand; Deleuze instead

20. Gilles Deleuze and Félix Guattari, Anti-Oedipus, Robert Hurley et al. (trans.) (New York: Viking, 1977), 334.

21. Ibid., 380.

22. Michel Tournier, The Wind Spirit: An Autobiography, Arthur Goldhammer (trans.) (Boston, MA: Beacon Press, 1988), 127-8.

23. Notes from this course have been preserved by one of Deleuze's students, Pierre Lefebvre, at www.webdeleuze.com (accessed August 2010).

${ }^{\star} 24$. For a discussion of Deleuze's work on Nietzsche, see the essay by Alan D. Schrift on "French Nietzscheanism" in this volume. 
received an assignment at the University of Lyon, where he taught from 1964 to 1969. But the meeting marked the beginning of a long and respectful intellectual friendship. ${ }^{25}$ In 1970, Foucault wrote an influential article on Deleuze, entitled "Theatricum Philosophicum," which was instrumental in introducing Deleuze's work to a broader public; ${ }^{26}$ Deleuze would later declare Foucault to be "the greatest thinker of our time."27 When Foucault's life was cut short in 1984, Deleuze devoted a year of his seminar to Foucault's writings, and the resulting book, he said, was written "out of necessity for me, out of admiration for him, out of my emotion at his death, at this interrupted work." 28

The years 1968 and 1969 were pivotal in Deleuze's life. In 1968, Deleuze presented and defended his thèse de doctorat d'état: his principal thesis was Difference and Repetition, directed by Gandillac, considered by many to be Deleuze's magnum opus; his secondary thesis was Spinoza and the Problem of Expression, directed by Alquié. These were followed, in 1969, by Logic of Sense, an analysis of the concept of sense oriented around a reading of Lewis Carroll and Stoicism. Some time during this period, Deleuze contracted a recurring respiratory ailment that would plague him for the rest of his life; he underwent a major lung operation for the condition in 1969, and although he said that the disease never seriously affected his ability to work, he was frequently absent from his courses in later years because of his illness. ${ }^{29}$ In the same year, he met Félix Guattari, a militant psychoanalyst, with whom he would write his most famous and well-read books, the two volumes of Capitalism and Schizophrenia (1972, 1980). The first volume, Anti-Oedipus, was an overtly political text written in the wake of the ferment of May 1968; it became a bestseller in France, and thrust Deleuze and Guattari into the limelight as public intellectuals. Deleuze was teaching in Lyon when the events of May 1968 erupted, and he was an immediate and unrelenting supporter of the student movement. "For my part," he later recalled, "I made a kind of passage into politics around May '68, as I

25. See Eribon, Michel Foucault, 136-8, for a brief account of the Foucault-Deleuze relationship. Deleuze and Foucault did not see each other after 1977, for reasons that were circumstantial (Foucault was teaching in Berkeley) as well as political. James Miller discusses the reasons for the supposed "break" in his biography, The Passion of Michel Foucault (New York: Simon \& Schuster, 1993), 297-8; both Foucault and Deleuze were protesting Germany's request that France extradite Klaus Croissant, a lawyer for the Baader-Meinhof gang, but whereas Foucault "couched his own position in terms of right," Deleuze went much further, and wanted "to protest what he regarded as Germany's 'state terrorism,' implicitly endorsing the image of the government held by the Baader-Meinhof gang itself” (ibid., 297).

26. Michel Foucault, “Theatrum Philosophicum," Critique 282 (1970).

27. Deleuze, Negotiations, 102.

28. Ibid.

29. Hugh Tomlinson, personal correspondence with the author, August 14, 1987. 
came into contact with specific problems, through Guattari, through Foucault, through Elie Sambar [founder of the Revue d'études palestiniennes]."30

During the 1970s, Deleuze would become politically active in a number of causes, including the Groupe d'information sur les prisons (formed by Foucault, among others), and he had an engaged concern with homosexual rights and the Palestinian liberation movement. Late in 1969, he took up a position at the University of Paris VIII-Vincennes, which was created as an "experimental" campus after the events of May 1968. Foucault, Châtelet, Serres, Étienne Balibar, Jacques Rancière, and Alain Badiou were all teaching there, although Foucault was named to the Collège de France the following year, and Serres left for the Sorbonne soon afterwards. Jean-François Lyotard joined the faculty in 1972, and he and Deleuze would collaborate on several projects (including writing a public letter condemning the dismissal of Luce Irigaray in 1974 from the Department of Psychoanalysis ${ }^{31}$ ). The Vincennes facilities were razed by the government in 1978 , and the faculty was transferred to a campus at Saint-Denis, a suburb north of Paris, where Deleuze remained until his retirement in 1987, holding weekly seminars every Tuesday morning. He never took up a joint appointment at an American university, as many of his contemporaries did, and he tended to shun academic conferences and colloquia, insisting that the activity of thought took place primarily in writing, and not in dialogue and discussion. Like Kant, he traveled little: France was his Prussia, and Paris his Königsberg. The only trip that ever counted for him, he said, was a trip to Florence, "perhaps"; 32 his sole trip to the United States took place in 1972, when he participated in a conference at Columbia University, organized by Sylvère Lotringer, on Anti-Oedipus. "If I don't travel," he explained, "I've taken motionless trips just like everyone else .... Some voyages take place in situ, they are trips in intensity." 33

In 1980, the second volume of Capitalism and Schizophrenia appeared, entitled A Thousand Plateaus, a highly experimental text, organized in a series of "plateaus" rather than chapters, which pushed Deleuze and Guattari's production of concepts (rhizome, becoming, the refrain, the war machine) to an entirely new level. In the 1980s, Deleuze and Guattari pursued their writing careers separately, with Deleuze's attention increasingly turned toward the arts: he published a book on painting (Francis Bacon: The Logic of Sensation; 1980), a two-volume study of the cinema (The Movement-Image; 1983; and The Time-Image; 1985),

30. Deleuze, Negotiations, 170, translation modified.

31. First published in December 1974 in Les Temps modernes, Deleuze and Lyotard's letter "Sur le Département de psychanalyse de Vincennes" appears in Jean-François Lyotard, Political Writings, Bill Readings and Kevin Paul Geiman (trans.) (Minneapolis, MN: University of Minnesota Press, 1993), 68-9.

32. Philippe Mengue, Gilles Deleuze ou le système du multiple (Paris: Éditions Kimé, 1994), 297-8.

33. Deleuze, Negotiations, 11, translation modified. 
an analysis of the Baroque (The Fold: Leibniz and the Baroque; 1988), and a collection of essays on literature (Essays Critical and Clinical; 1993). Deleuze's final collaboration with Guattari, What is Philosophy? was published in 1991. Guattari died of a heart attack in 1992; by 1993, Deleuze's pulmonary illness had confined him severely, making it increasingly difficult to read or write; he took his own life by defenestration, on the night of November 4, 1995. Since then, additional material from Deleuze's corpus has come to light. Two volumes of Deleuze's occasional texts and interviews were collected and edited by David Lapoujade, a former student, and published as Desert Islands (2002) and Two Regimes of Madness (2003). Richard Pinhas, another former student, is in the process of making transcriptions of Deleuze's seminars available at webdeleuze. com, which is an invaluable resource for those interested in the development of Deleuze's philosophy.

In What is Philosophy? Deleuze and Guattari famously define philosophy as "the art of forming, inventing, and fabricating concepts," although this creation of concepts always takes place under the constraint of changing problematics that are as much historical and social as they are philosophical. ${ }^{34}$ For Deleuze, concepts are the medium within which philosophers work - just as painters work with lines and colors, filmmakers work with images, and musicians work with sounds - and his work was marked throughout by an extraordinary conceptual inventiveness. Deleuze rejected the Heideggerian theme of the end of metaphysics, and much of his own conceptual production was aimed at developing a metaphysics adequate to contemporary mathematics and science: a metaphysics in which the concept of multiplicity replaces that of substance, event replaces essence, virtuality replaces possibility, and so on. "I feel myself to be a pure metaphysician," he noted, "Bergson says that modern science hasn't found its metaphysics, the metaphysics it would need. It is this metaphysics that interests me." ${ }^{35}$ But Deleuze's metaphysics is a resolutely post-Kantian metaphysics in that it refuses to admit the three "transcendent illusions" criticized by Kant in the Critique of Pure Reason: God, the World, and the Self. Although Deleuze's early work is often read as a reaction against Hegel, Deleuze's more general project can be seen as a reassessment of the then-dominant post-Kantian tradition in philosophy. Kant's genius, for Deleuze, was to have conceived a

34. Gilles Deleuze and Félix Guattari, What is Philosophy?, Hugh Tomlinson and Graham Burchell (trans.) (New York: Columbia University Press, 1994), 2.

35. Gilles Deleuze, "Réponses à une série de questions," interview with Arnaud Villani, which appears as an appendix to Arnaud Villani, La Guêpe et l'orchidée: Essai sur Gilles Deleuze (Paris: Belin, 1999), 129-31, esp. 130. An English translation, under the title "Responses to a Series of Questions," can be found in the journal Collapse 3 (2007), 39-43. 
purely immanent critique of reason: a critique that did not seek, within reason, "errors" produced by external causes, but rather "illusions" that arise internally from within reason itself by the illegitimate (transcendent) uses of the syntheses of consciousness. Deleuze characterized his own work as a philosophy of immanence, but argued that Kant himself had failed to fully realize the immanent ambitions of his critique, for at least two reasons.

First, Kant made the immanent field immanent to a transcendental subject, thereby reintroducing an element of transcendence, and reserving all power of synthesis to the activity of the subject. Deleuze's first book, on Hume, had pointed to an empiricist reversal of this relation: whereas Kant's question had been "How can the given be given to a subject?" Hume's question had been "How is the subject (human nature) constituted within the given?" Deleuze would later characterize his own position as a "transcendental empiricism": the determination of an impersonal and pre-individual transcendental field in which the subject is itself the result or product of passive syntheses (of the body, habit, desire, the unconscious). Just as there is no universal reason but only historically variable processes of "rationalization" (Max Weber), so there is no universal or transcendental subject, but only diverse and historically variable processes of "subjectivation." Deleuze summarized his empiricism in terms of two characteristics: (i) the abstract does not explain, but must itself be explained; (ii) the aim of philosophy is not to rediscover the eternal or the universal, but to find the singular conditions under which something new is produced (creativity).

Second, Kant had simply presumed the existence of certain "facts" (knowledge, morality) and then sought their conditions of possibility in the transcendental. But already in 1789, Salomon Maimon, whose early critiques of Kant helped generate the post-Kantian tradition, had argued that Kant's critical project required a method of genesis - and not merely a method of conditioning - that would account for the production of knowledge, morality, and indeed reason itself - a method, in other words, that would be able to reach the conditions of real and not merely possible experience. Maimon found a solution to this problem in a principle of difference: whereas identity is the condition of possibility of thought in general, it is difference that constitutes the genetic and productive principle of real thought. These two Maimonian exigencies - the search for the genetic conditions of real experience and the positing of a principle of difference - reappear like a leitmotif in almost every one of Deleuze's early monographs. Nietzsche and Philosophy, for instance, suggests that Nietzsche completed and inverted Kantianism by bringing critique to bear, not simply on false claims to knowledge or morality, but on true knowledge and true morality, and indeed on truth itself: "genealogy" constituted Nietzsche's genetic method, and the will to power was his principle of difference. In Bergsonism, on the other hand, Deleuze argues that Bergson's concepts of duration, memory, and 
élan vital constitute the differential and genetic dimensions of the multiplicities of the real. Against the "major" post-Kantian tradition of Fichte, Schelling, and Hegel, Deleuze in effect posited his own "minor" post-Kantian trio of Maimon, Nietzsche, and Bergson. In rethinking the post-Kantian heritage, Deleuze would also retrieve the work of a well-known trio of pre-Kantian philosophers - Hume, Spinoza, and Leibniz - although from a decidedly post-Kantian viewpoint.

Deleuze's historical monographs were, in this sense, preliminary sketches for the great canvas of Difference and Repetition, which marshaled these resources from the history of philosophy in an ambitious project to construct a metaphysics of difference. Normally, difference is conceived of as an empirical relation between two terms each of which have a prior identity of their own (" $x$ is different from $y^{\prime \prime}$ ). In Deleuze, this primacy is inverted: identity persists, but it is now a secondary principle produced by a prior relation between differentials $(d x$ rather than not- $x$ ). Difference is no longer an empirical relation but becomes a transcendental principle that constitutes the sufficient reason of empirical diversity as such (for example, it is the difference of potential in a cloud that constitutes the sufficient reason of the phenomenon of lightning). In Deleuze's ontology, the different is related to the different through difference itself, without any mediation. Although he was indebted to metaphysical thinkers such as Spinoza, Leibniz, and Bergson, Deleuze appropriated their respective systems of thought only by pushing them to their "differential" limit, purging them of the three great terminal points of traditional metaphysics (God, World, Self).

Deleuze's subsequent work was, to some degree, a further working out of the metaphysics developed in Difference and Repetition. "I believe in philosophy as a system," Deleuze once wrote, "For me, the system must not only be in perpetual heterogeneity, it must be a heterogenesis, which, it seems to me, has never been attempted." ${ }^{36}$ Heterogenesis: this means that the system itself must entail the genesis of the heterogeneous, or the production of the new (a dynamic and open system), which in turn means that the concepts themselves are dynamic and open. "It is not a question of bringing things together under a single concept, but rather of relating each concept to the variables that explain its mutations." ${ }^{37}$ Consider, for example, the notion of intensity: in Difference and Repetition, it is linked to a notion of depth; in Logic of Sense, it is linked to the concept of surface; in Anti-Oedipus, it is what takes place on a body without organs; in What is Philosophy? it marks the nature of the components of a concept. ${ }^{38}$ The

36. "Preface," in Jean-Clet Martin, Variations: La Philosophie de Gilles Deleuze (Paris: Payot, 1993), 7.

37. Deleuze, Negotiations, 31, translation modified.

38. Deleuze himself points out the mutation of the concept of intensity in his "Author's Note for the Italian Edition of Logic of Sense," in Two Regimes of Madness: Texts and Interviews 19751995, Ames Hodges and Mike Taormina (trans.) (New York: Semiotext(e), 2006), 65-6. 
consistency of a concept, in other words, has as its necessary correlate the variability of the concept. For these reasons, it is impossible to summarize Deleuze's system, but we can at least give a sense of the problems that generate it by considering five philosophical domains that more or less parallel those laid out in the architectonic of Kant's Critiques: dialectics, aesthetics, ethics, politics, analytics.

1. Dialectics (Theory of the Idea). Difference and Repetition attempts to formulate a theory of Ideas (dialectics) based on neither an essential model of identity (Plato), nor a regulative model of unity (Kant), nor a dialectical model of contradiction (Hegel), but rather on a problematic and genetic model of difference. Ideas are what define the "essence" of a thing, but one cannot attain an Idea through the Socratic question "What is ...?" (which posits Ideas as transcendent and eternal), but rather through "minor" questions such as "Which one?" "Where?" "When?" "How?" "How many?" "In which case?" "From which viewpoint?" - all of which allow one to define the spatiotemporal coordinates of Ideas that are immanent and differential. Kant posited Ideas as "regulative" notions that serve to unify and systematize the operations of the understanding: concepts find the ground of their maximal experimental use only insofar as they are related to Ideas, which Kant defines as foci or horizons that lie outside the bounds of experience. But an object outside experience can be represented only in a problematic form: it can neither be given nor known, but must be represented without being able to be directly determined. This undetermined object of the Idea marks neither an imperfection in our knowledge nor a lack in the object: it is a perfectly positive and objective structure that allows us to represent other objects (those of experience) which it endows with a maximum of systematic unity. In Kant, then, Ideas present three aspects: they are undetermined with regard to their object, but nonetheless determinable with regard to the objects of experience, and bear the ideal of a complete determination with regards to the concepts of the understanding.

Because he held fast to the point of view of conditioning, however, two of these three moments remain as extrinsic characteristics in Kant. In Difference and Repetition, Deleuze aims to develop a theory of problematic Ideas that is genetic and not merely conditioning, following Maimon's contention that the duality between concepts and intuitions can be bridged only by positing ideas of difference within sensibility itself. The formal criteria Deleuze uses to define Ideas are largely derived from Leibniz and the model of the differential calculus, which provides a mathematical symbolism for the exploration of the real: things or beings are virtual and problematic multiplicities composed of singularitiesevents, which are prolonged in converging and diverging series, forming zones of indiscernibility where the multiplicities enter into perpetual becomings. Drawing on the work of Jules Vuillemin and Albert Lautman, among others, in 
the philosophy of mathematics, Deleuze defines the three moments of the Idea in a purely intrinsic and differential manner: (i) it implies elements that in themselves are completely undetermined $(d x, d y)$; (ii) these elements are nonetheless determinable reciprocally in the differential relation $(d y / d x)$, which (iii) defines their complete determination as a singular point (values of $d y$ and $d x$ ). For Lautman, the conditions of a problem are constituted by the nomadic and virtual distribution of these singular points, and the solution appears only with the integral curves that constitute the actualization of certain singularities. Deleuze thus defines the problematic structure of an Idea as an internal multiplicity, a system of multiple, nonlocalizable connections between differential elements, in which difference is related to difference through difference. The genesis takes place in time, not between one actual term and another, but between the virtual and its actualization, that is, it goes from the condition of the problem to cases of solution, from the differential elements and their ideal connections to the actual terms and diverse real relations that constitute the actuality of time. Whereas Kantian Ideas are unifying and conditioning, Deleuzian Ideas are differential and genetic.

Perhaps Deleuze's most famous - and most misunderstood - concept is that of the virtual, which has nothing to do with an alternate or transcendent reality (as in the notion of "virtual reality"). Rather, it is a concept Deleuze utilizes in order to designate the modal status of problematic Ideas, and which he systematically contrasts with the concept of the possible: an Idea is not a locus of possibilities, but a field of virtualities. We tend to think of the possible as somehow "pre-existing" the real, and we think of the real as something more than the possible, that is, as the possible with existence added to it. But the drawback of this conception of the possible is that the identity of a thing is already given in the concept, and simply has existence added to it when it is "instantiated" or "realized." This process of realization, Deleuze suggests, is subject to two rules: resemblance (the real resembles the possibility that it realizes) and limitation (in the process of realization, some possibilities are repulsed or thwarted, while others "pass" into the real). But this is where the sleight of hand becomes obvious: if the real is supposed to resemble the possible, is it not because we have retrospectively "projected" a fictitious image of the real back into the possible? In fact, it is not the real that resembles the possible, but the possible that resembles the real. For this reason, the concept of the possible can never grasp the production of the new, or the genesis of difference. Deleuze's proposal, therefore, is to replace the possible-real couple with the virtual-actual couple. The reality of the virtual is the reality of the problematic, that is, the reality of the Idea, while the rules of actualization are not resemblance and limitation, but differenciation or divergence (creation). The concept of the virtual is synonymous with the Deleuzian notion of differen-t/c-iation: a problematic is completely differentiated (by its 
differential relations and singularities), while every actualization of a problem is a movement of differenciation, that is, the production of a new difference. As such, the concept of the virtual fulfills the demands of a philosophy of difference: difference is related to difference through difference itself.

2. Aesthetics (Theory of Sensation). What are the implications of a principle of difference for aesthetics? Kant had dissociated aesthetics into two halves: the theory of sensibility as the form of possible experience (the "Transcendental Aesthetic"), and the theory of art as a reflection on real experience (the "Critique of Aesthetic Judgment"). In Deleuze's work, these two halves of aesthetics are reunited: if the most general aim of art is to "produce a sensation," then the genetic principles of sensation are at the same time the principles of composition for works of art; conversely, it is works of art that are best capable of revealing these conditions of sensibility. Deleuze's writings on the various arts - including the cinema (Cinema I, Cinema II), literature (Essays Critical and Clinical), and painting (Francis Bacon: The Logic of Sensation) - must be read not as works of criticism, but rather as philosophical explorations of this transcendental domain of sensibility. Deleuze locates the conditions of sensibility in an intensive conception of space and a virtual conception of time, which are necessarily actualized in a plurality of spaces and a complex rhythm of times (for instance, in the nonextended spaces and nonlinear times of modern mathematics and physics).

Deleuze's interpretation of Leibniz's famous theory of perception provides a useful example of his method. Leibniz argued that a conscious perception must be related not to objects situated in space and time, but to the minute perceptions of which it is composed. I apprehend the noise of the sea or the murmur of a crowd, but not the sound of each wave or each voice of which it is composed. These unconscious perceptions are related to conscious perceptions, not as parts to a whole, but as what is ordinary to what is remarkable or singular: a conscious perception is produced when at least two of these elements enter into a differential relation that determines a singularity. Or consider the color green: yellow and blue can be perceived, but if they reach a point where they become indiscernible, they enter into a differential relation that determines the color green $(d b / d y=\mathrm{G})$; in turn, yellow or blue, each on its own account, may be determined by the differential relation of two colors we cannot detect $(d x d y$ $=\mathrm{Y}$ ). These unconscious perceptions constitute the "ideal genetic elements" of perception, or what Maimon called the "differentials of consciousness." It is such a virtual multiplicity of genetic elements, and the system of connections established between them, that constitutes an Idea: the relations are actualized in diverse spatiotemporal relationships, just as the elements are actualized in diverse perceptions and forms. Rather than perception presupposing an object capable of affecting us, it is the reciprocal determination of differentials $(d x / d y)$ 
that entails both the complete determination of the object as perception and the determinability of space-time as conditions. Space-time ceases to be a given in order to become the totality or nexus of differential relations in the subject, and the object ceases to be an empirical given in order to become the product of these relations in conscious perception.

3. Ethics (Theory of Affectivity). Deleuze has similarly developed a purely immanent conception of ethics, an "ethics without morality." If morality implies an appeal to transcendent values as criteria of judgment (as in Kant's moral law), ethics evaluates actions and intentions according to the immanent mode of existence they imply. One says or does this, thinks or feels that: What mode of existence does it imply? This is the link Deleuze establishes between Spinoza and Nietzsche, his two great precursors as philosophers of immanence: each of them argued, in his own manner, that there are things one cannot do or think except on the condition of being base or enslaved, unless one harbors a ressentiment against life (Nietzsche), unless one remains the slave of passive affections (Spinoza); and there are other things one cannot do or say except on the condition of being noble or free, unless one affirms life or attains active affections. The transcendent moral opposition (Good/Evil) is in this way replaced by an immanent ethical difference (good/bad). A bad or sickly life is an exhausted and degenerating mode of existence, one that judges life from the perspective of its sickness, that devalues life in the name of higher values. A good or healthy life, by contrast, is an overflowing or ascending mode of existence, capable of transforming itself depending on the forces it encounters, always opening up new possibilities of life, new becomings.

For Deleuze, modes of existence can be evaluated according to the purely immanent criteria of affectivity, that is, by their capacity to affect and to be affected - a capacity that is not a simple logical possibility but is necessarily actualized at every moment, thus fulfilling the demand for a genetic principle of the real. If the greatness of Nietzsche's theory of nihilism was to have analyzed the process of becoming-reactive, the aim of Spinoza's Ethics was to outline the process of becoming-active. These two processes, however, necessarily coexist in any mode of existence, and for Deleuze the aim of ethical theory is to determine, not universal grounds or normative foundations, but rather the conditions under which the attainment of active affections is possible - or more precisely, the conditions under which the production of new modes of existence is possible, since the "activity" of a mode is defined by its ability to affect or transform itself. In his later work, Foucault, under a Deleuzian inspiration, coined the term "subjectivation" ("subjectivation") to define the means through which modes of existence are produced. In the later volumes of The History of Sexuality, Foucault analyzed the variable forms these affective processes took in the Greek 
("know yourself"), Roman ("master yourself"), and Christian ("renounce yourself") periods. It may be that the creators of new modes of existence are the "nobles" (Nietzsche), or the aestheticized "free man" (Foucault); under different conditions, however, they may also be the excluded, the minorized, the marginalized (Deleuze). The study of variations in the process of subjectivation is one of the fundamental positive tasks posed by an immanent conception of ethics.

4. Politics (Socio-Political Theory). This immanent conception of ethics leads directly into Deleuze's political philosophy, which he developed most fully in the two volumes of Capitalism and Schizophrenia, coauthored with Guattari. AntiOedipus, under the guise of a critique of psychoanalysis, is in effect an immanent reworking of Kant's theory of desire in the Critique of Practical Reason. For Deleuze, the link between ethics and politics is redefined as the link between desire and power: desire (the difference between active and reactive forces in a given mode of existence) never exists in a spontaneous or natural state, but is always "assembled" (agencé) in variable but determinable manners in concrete social formations, and what assembles desire are relations of power. Deleuze remains a "Marxist" in that his social theory is necessarily tied to an analysis of capitalism, which he defines by the conjunction or differential relation between the virtual quantities of labor and capital. What he calls "schizophrenia" is an absolute limit that would cause these quantities to travel in a free and unbound state on a desocialized body: this is the "Idea" of society, a limit that is never reached as such, but constitutes the ideal "problematic" to which every social formation constitutes a concrete solution. For Deleuze, the central political question concerns the means by which the singularities and states of difference of the transcendental field are assembled in a given socius. Capitalism and Schizophrenia consequently outlines a typology of four abstract social formations - "primitive" or segmentary societies, states, nomadic "war machines," and capitalism itself - that aims to provide the conceptual tools for analyzing the diverse dimensions of concrete social structures: How are its mechanisms of power organized? What are the "lines of flight" that escape its integration? What new modes of existence does it make possible? These types of social formations are not to be understood as stages in a progressive evolution or development; rather, they sketch out a topological field in which each type functions as a variable of coexistence that enters into complex relations with the other types.

5. Analytics (Theory of the Concept). Finally, Deleuze's dialectic (the constitution of problems) leads directly into his analytic (concepts as cases of solution), which he presented in his late book What is Philosophy? Deleuze defines philosophy as the creation of concepts, as knowledge through pure concepts. But for Deleuze, the highest concepts are not a priori universals applicable to objects of 
possible experience (categories), but singularities that correspond to the structures of real experience. What Is Philosophy? defines philosophical concepts in terms of three components:

(i) Endo-consistency. A concept is composed of a finite number of heterogenous and singular components that it renders consistent in itself; concepts have no extension, but only what Deleuze terms "intensive ordinates." For example, the Cartesian concept of the cogito presents three components doubting, thinking, and being - each of which has certain phases (perceptual, scientific, obsessional doubt) and between which there are zones of neighborhood (myself who doubts, I cannot doubt that I think).

(ii) Exo-consistency. Concepts enter into determinable relations of consistency with other concepts, both internally (a concept's components can be considered as concepts in their own right) and externally (concepts create their own bridges or links with other concepts). In Descartes, the idea of infinity provides an external bridge leading from the concept of the cogito to the concept of God, a new concept having three components that form the "proofs" for the existence of God.

(iii) Self-referentiality. Finally, concepts have no reference, but posit both themselves and their object in being created. When Kant "criticized" Descartes by introducing time as a component of the cogito, he effectively created a new concept with a new object.

More than most of his contemporaries, Deleuze insisted on the autonomy of philosophy as a discipline, arguing forcefully for the irreducibility of philosophical concepts to scientific functions or logical propositions. Deleuze contrasts the reference of functions with the consistency of concepts: what Deleuze calls a "function" is always defined in relation to an actualized virtual (which finds its reference in a state of things, an object, or lived experience), whereas philosophical concepts are defined by the consistency they give to the virtual as such. Consequently, philosophical concepts are not propositional, and do not form a discursive whole; they are rather fragmentary totalities with irregular contours that "freely enter into relationships of nondiscursive resonance." ${ }^{39}$

Taken together, these five rubrics, although certainly not exhaustive, nonetheless serve to present the broad outlines of a systematic philosophy of difference as it appears in Deleuze's work. Critics have posed objections in each of these domains: How can a differential "logic of sensation" imply a theory of art without first addressing the conceptual question "What is art?" - a question Duchamp's

39. Deleuze and Guattari, What is Philosophy?, 23. 
works threw down like a gauntlet to the twentieth century? According to what criteria can one assess the validity of a philosophical concept if it creates its object simply by being posited, and has no "referent"? Does not a differential ethics amount to a kind of moral nihilism in which all differences are in turn affirmed as equally valid (as Jürgen Habermas has charged), or an aestheticism in which ethics is reduced to a private search for autonomy or self-invention (as Richard Rorty claimed)? Such criticisms, and others like them, can be summed up in the reproach that a philosophy of difference seems unable (or unwilling) to put forward normative criteria of judgment in any domain, and in this sense it fails in the "critical" task that Kant himself assigned to philosophy. In response, Deleuze insisted that one of the significant consequences of a philosophy of difference is its shift in emphasis away from the universal toward the singular and the new: only a principle of difference is capable of providing a rigorous response to the question of heterogenesis: "What are the conditions for the production of the new?" (artistic creation, conceptual innovation, social change). ${ }^{40}$

\section{MAJOR WORKS}

Empirisme et subjectivité. Paris: Presses Universitaires de France, 1953. Published in English as Empiricism and Subjectivity, translated by Constantin Boundas. New York: Columbia University Press, 1991.

Nietzsche et la philosophie. Paris: Presses Universitaires de France, 1962. Published in English as Nietzsche and Philosophy, translated by Hugh Tomlinson. Minneapolis, MN: University of Minnesota Press, 1983.

La Philosophie critique de Kant. Paris: Presses Universitaires de France, 1963. Published in English as The Critical Philosophy of Kant, translated by Hugh Tomlinson and Barbara Habberjam. Minneapolis, MN: University of Minnesota Press, 1984.

Proust et les signes. Paris: Presses Universitaires de France, 1964, 1970, 1976. Published in English as Proust and Signs. The Complete Text, translated by Richard Howard. Minneapolis, MN: University of Minnesota Press, 2003.

Le Bergsonisme. Paris: Presses Universitaires de France, 1966. Published in English as Bergsonism, translated by Hugh Tomlinson and Barbara Habberjam. New York: Zone Books, 1988.

Présentation de Sacher-Masoch. Paris: Éditions de Minuit, 1967. Published in English as Masochism: An Interpretation of Coldness and Cruelty, translated by Jean McNeil. New York: G. Braziller, 1971.

Différence et répétition. Paris: Presses Universitaires de France, 1968. Published in English as Difference and Repetition, translated by Paul Patton. New York: Columbia University Press, 1994.

Spinoza et le problème de l'expression. Paris: Éditions de Minuit, 1968. Published in English as Expressionism in Philosophy: Spinoza, translated by Martin Joughin. New York: Zone Books, 1990.

40. This essay is dedicated to the memory of François Zourabichvili, who was both a great friend and a great philosopher, and whose writings on Deleuze set such a high standard of rigor and insight that those of us who follow in his wake can only vainly hope to emulate it. 
Logique du sens. Paris: Éditions de Minuit, 1969. Published in English as The Logic of Sense, translated by Mark Lester with Charles Stivale. New York: Columbia University Press, 1990.

Spinoza: Philosophie pratique. Paris: Presses Universitaires de France, 1970. 2nd ed. 1981. Published in English as Spinoza: Practical Philosophy, translated by Robert Hurley. San Francisco: City Lights Books, 1988.

L'Anti-Oedipe (with Félix Guattari). Paris: Éditions de Minuit, 1972. Published in English as AntiOedipus, translated by Robert Hurley, Mark Seem, and Helen R. Lane. New York: Viking, 1977.

Kafka: pour une littérature mineure (with Félix Guattari). Paris: Éditions de Minuit, 1975. Published in English as Kafka: Toward a Minor Literature, translated by Dana Polan. Minneapolis, MN: University of Minnesota Press, 1986.

Dialogues (with Claire Parnet). Paris: Flammarion, 1977. Published in English as Dialogues, translated by Hugh Tomlinson and Barbara Habberjam. New York: Columbia University Press, 1987.

Mille plateaux (with Félix Guattari). Paris: Éditions de Minuit, 1980. Published in English as A Thousand Plateaus, translated by Brian Massumi. Minneapolis, MN: University of Minnesota Press, 1987.

Francis Bacon: Logique de la sensation. Paris: Editions de la différence, 1981. Published in English as Francis Bacon: Logic of Sensation, translated by Daniel W. Smith. Minneapolis, MN: University of Minnesota Press, 2005.

Cinéma I: L'Image-Mouvement. Paris: Éditions de Minuit, 1983. Published in English as Cinema I: The Movement-Image, translated by Hugh Tomlinson and Barbara Habberjam. Minneapolis, MN: University of Minnesota Press, 1986.

Cinéma II: L'Image-temps. Paris: Éditions de Minuit, 1985. Published in English as Cinema II: The Time-Image, translated by Hugh Tomlinson and Robert Galeta. Minneapolis, MN: University of Minnesota Press, 1989.

Foucault. Paris: Éditions de Minuit, 1986. Published in English as Foucault, translated by Seán Hand. Minneapolis, MN: University of Minnesota Press, 1988.

Le Pli: Leibniz et le Baroque. Paris: Éditions de Minuit, 1988. Published in English as The Fold: Leibniz and the Baroque, translated by Tom Conley. Minneapolis, MN: University of Minnesota Press, 1993.

Pourparlers. Paris: Éditions de Minuit, 1990. Published in English as Negotiations, 1972-1990, translated by Martin Joughin. New York: Columbia University Press, 1995.

Qu'est-ce que la philosophie? (with Félix Guattari). Paris: Éditions de Minuit, 1991. Published in English as What is Philosophy?, translated by Hugh Tomlinson and Graham Burchell. New York: Columbia University Press, 1994.

Critique et clinique. Paris: Éditions de Minuit, 1993. Published in English as Essays Critical and Clinical, translated by Daniel W. Smith and Michael Greco. Minneapolis, MN: University of Minnesota Press, 1997.

LÎle déserte et autres textes: Textes et entretiens 1953-1974. Edited by David Lapoujade. Paris: Éditions de Minuit, 2002. Published in English as Desert Islands and Other Texts (1953-1974), translated by Mike Taormina. New York: Semiotext(e), 2003.

Deux régimes de fous: Textes et entretiens 1975-1995. Edited by David Lapoujade. Paris: Éditions de Minuit, 2003. Published in English as Two Regimes of Madness: Texts and Interviews 1975-1995, translated by Ames Hodges and Mike Taormina. New York: Semiotext(e), 2006. 